\title{
Antes do café da manhã
}

\author{
Eduardo Freitas de Souza
}

\begin{abstract}
Resumo: A Sra. Rowland acorda de manhã cedo e, com os nervos à flor da pele, já começa a beber e a reclamar da vida com Alfred, seu marido, que está no quarto ao lado e de quem só vemos a mão a uma certa altura e ouvimos um gemido. A Sra. Rowland mostra-nos sua perspectiva de seu casamento, da sua infelicidade e da sua desesperança.
\end{abstract}

Palavras-chave: Eugene O’Neill; peça de um ato; teatro norte-americano; tragédia moderna; monólogo.

\section{Tradução de Before Breakfast}

O’Neill é um grande contador de histórias. Um dos melhores que conheço. E é um grande estilista. Um grande dialoguista. Seus diálogos têm linda melodia, e um ritmo todo próprio; a melopeia de que fala Pound ${ }^{1}$. Como com qualquer bom autor teatral que se traduz, o desafio é traduzir o ritmo de seu estilo, como dizia Nietzsche ${ }^{2}$, a música de sua prosa e de seus diálogos. Como transmitir o conteúdo da peça e dar-lhe uma forma semelhante, que esteja à altura do original?! Trabalho nada fácil. Tem-se que pensar na frase que se quer, tem-se que dizer a frase para ver se ela soa bem e se está boa para ser dita por um ator. Tem-se que ler a peça em vOz alta para ver se se conseguiu alguma musicalidade similar à do texto original. Em literatura, tem-se que traduzir a forma tanto quanto o conteúdo. Tem-se que transformar um texto verbal artístico em outro texto verbal artístico. Trata-se de

1 MILTON, John. TraduçãoTeoria e Prática. São Paulo: Martins Fontes, 1998, p. 81.

2 BIGUENET, John. Theories of Translation: an Anthology of Essays from Dryden to Derrida. Chicago: University of Chicago Press, 1992. 
beleza, de se imitar uma coisa bela. E não é fácil. Tem-se que entrar no espírito do original, capturar-lhe a beleza da relação conteúdo/forma, e reproduzir este espírito em outra língua, e produzir outro texto que seja belo e que transmita (possivelmente) a mesma mensagem do texto original.

Before Breakfast foi um texto que quis traduzir de imediato. O’Neill inspirou-se em The Stronger, de Strindberg, sua grande influência. De Alfred só se vê a mão e se ouve um grito e um gemido. Mas a Sra. Rowland conta-nos tudo a respeito dele, a respeito dos dois. É uma tragédia moderna. Assiste-se (lê-se) à fragilidade da vida, das relações humanas, de uma relação sentimental, da falta e da falha da comunicação, do fracasso de duas vidas e da decorrente infelicidade, do desastre. Vemos que a vida pode não ter sentido, ser caótica, brutal, uma experiência terrível, sem esperanças, e que as relações amorosas são muito difíceis, e que ainda assim precisamos encontrar um jeito de suportá-la. O’Neill dá uma aula de sensibilidade, de humanidade, de fragilidade, de tristeza, de dor. E a tarefa do tradutor é reproduzir isso em outra língua. Usar as palavras certas. Construir as frases certas. Não é uma tarefa fácil. Mas é gratificante quando achamos que, pelo menos em parte, conseguimos. É a chance de uma pessoa comum produzir um objeto de arte, de contribuir para o encanto do mundo com um objeto de beleza, traduzindo um grande autor. É esta a recompensa do tradutor.

\section{Before Breakfast (Eugene O’Neill) ${ }^{3}$}

\section{CHARACTERS- MRS. ROWLAND}

SCENE-A small room serving both as kitchen and dining room in a flat on Christopher Street, New York City. In the rear, to the right, a door leading to the outer hallway. On the left of the doorway, a sink, and a two-burner gas stove. Over the stove, and extending to the left wall, a wooden closet for dishes, etc. On the left, two windows looking out on a fire escape where several potted plants are dying of neglect. Before the windows, a table covered with oilcloth. Tunn crno-hnttnmed shairs are placed by the table. Another stands against the wall to the right of door in rear. In the right wall, rear, a doorway leading into a bedroom. Farther forward, different articles of a man's and a woman's clothing are hung on pegs. A clothes line is strung from the left corner, rear, to the right wall, forward.

3 O’NEILL, Eugene. www.eoneill.com/texts/bb/contents.htm 
It is about eight-thirty in the morning of a fine, sunshiny day in the early fall.

Mrs. Rowland enters from the bedroom, yawning, her hands still busy putting the finishing touches on a slovenly toilet by sticking hairpins into her hair which is bunched up in a drab-colored mass on top of her round head. She is of medium height and inclined to a shapeless stoutness, accentuated by her formless blue dress, shabby and worn. Her face is characterless, with small, regular features and eyes of a nondescript blue. There is a pinched expression about her eyes and nose and her weak, spiteful mouth. She is in her early twenties but looks much older.

She comes to the middle of the room and yawns, stretching her arms to their full length. Her drowsy eyes stare about the room with the irritated look of one to whom a long sleep has not been a long rest. She goes wearily to the clothes hanging on the right and takes an apron from a book. She ties it about her waist, giving vent to an exasperated "damn" when the knot fails to obey her clumsy fingers. Finally gets it tied and goes slowly to the gas stove and lights one burner. She fills the coffee pot at the sink and sets it over the flame. Then slumps down into a chair by the table and puts a hand over her forehead as if she were suffering from headache. Suddenly her face brightens as though she had remembered something, and she casts a quick glance at the dish closet; then looks sharply at the bedroom door and listens intently for a moment or so.

MRS. ROWLAND_-(In a low voice) Alfred! Alfred! (There is no answer from the next room and she continues suspiciously in a louder tone) You needn't pretend you're asleep. (There is no reply to this from the bedroom, and, reassured, she gets up from her chair and tiptoes cautiously to the dish closet. She slowly opens one door, taking great care to make no noise, and slides out, from their hiding place behind the dishes, a bottle of Gordon gin and a glass. In doing so she disturbs the top dish, which rattles a little. It this sound she starts guiltily and looks with sulky defiance at the doorway to the next room.)

(Her voice trembling) Alfred!

After a pause, during which she listens for any sound, she takes the glass and pours out a large drink and gulps it down; then hastily returns the bottle and glass to their hiding place. She closes the closet door with the same care as she had opened it, and, heaving a great sigh of relief, sinks down into her chair again. The large dose of alcohol she has taken has an almost immediate effect. Her features become more animated, she seems to gather energy, and she looks at the bedroom door with a hard, vindictive smile on her lips. Her eyes glance quickly about the room and are fixed on a man's coat and vest which hang from a hook at right. She moves stealthily over to the open doorway and stands there, out of sight of anyone inside, listening for any movement.)

(Calling in a half-whisper) Alfred!

(Again there if no reply. With a swift movement she takes the coat and vest from the hook and returns with them to her chair. She sits down and takes the various articles out of 
each pocket but quickly puts them back again. At last, in the inside pocket of the vest, she finds a letter.)

(Looking at the handwriting-slowly to herself) Hmm! I knew it.

(She opens the letter and reads it. At first her expression is one of hatred and rage, but as she goes on to the end it changes to one of triumphant malignity. She remains in deep thought for a moment, staring before her, the letter in her hands, a cruel smile on her lips. Then she puts the letter back in the pocket of the vest, and still careful not to awaken the sleeper, hangs the clothes up again on the same hook, and goes to the bedroom door and looks in.)

(In a loud, shrill voice) Alfred! (Still louder) Alfred! (There is a muffled, yawning groan from the next room) Don't you think it's about time you got up? Do you want to stay in bed all day? (Turning around and coming back to her chair) Not that I've got any doubts about your being lazy enough to stay in bed forever. (She sits down and looks out of the window, irritably) Goodness knows what time it is. We haven't even got any way of telling the time since you pawned your watch like a fool. The last valuable thing we had, and you knew it. It's been nothing but pawn, pawn, pawn, with you - anything to put off getting a job, anything to get out of going to work like a man. (She taps the floor with her foot nervously, biting her lips.)

(After a shortpause) Alfred! Get up, do you hear me? I want to make that bed before I go out. I'm sick of having this place in a continual mess on your account. (With a certain vindictive satisfaction) Not that we'll be here long unless you manage to get some money some place. Heaven knows I do my part_-and more-going out to sew every day while you play the gentleman and loaf around barrooms with that good-for-nothing lot of artists from the Square.

(A short pause during which she plays nervously with a cup and saucer on the table.)

And where are you going to get money, I'd like to know? The rent's due this week and you know what the landlord is. He won't let us stay a minute over our time. You say you can't get a job. That's a lie and you know it. You never even look for one. All you do is moon around all day writing silly poetry and stories that no one will buy — and no wonder they won't. I notice I can always get a position, such as it is; and it's only that which keeps us from starving to death.

(Gets up and goes over to the stove-looks into the coffee pot to see if the water is boiling; then comes back and sits down again.)

You'll have to get money today some place. I can't do it all, and I won't do it all. You've got to come to your senses. You've got to beg, borrow, or steal it somewhere. (With a contemptuous laugh) But where, I'd like to know? You're too proua to Dey, and you've borrowed the limit, and you haven't the nerve to steal. 
(After a pause — getting up angrily) Aren't you up yet, for heaven's sake? It's just like you to go to sleep again, or pretend to. (She goes to the bedroom door and looks in) Oh, you are up. Well, it's about time. You needn't look at me like that. Your airs don't fool me a bit any more. I know you too well—better than you think I do-you and your goings-on. (Turning away from the door-meaningly) I know a lot of things, my dear. Never mind what I know, now. I'll tell you before I go, you needn't worry. (She comes to the middle of the room and stands there, frowning.)

(Irritably) Hmm! I suppose I might as well get breakfast ready-not that there's anything much to get. (Questioningly) Unless you have some money? (She pauses for an answer from the next room which does not come) Foolish question! (She gives a short, hard langh) I ought to know you better than that by this time. When you left here in such a huff last night I knew what would happen. You can't be trusted for a second. A nice condition you came home in! The fight we had was only an excuse for you to make a beast of yourself. What was the use pawning your watch if all you wanted with the money was to waste it in buying drink?

(Goes over to the dish closet and takes out plates, cups, etc., while she is talking.)

Hurry up! It don't take long to get breakfast these days, thanks to you. All we got this morning is bread and butter and coffee; and you wouldn't even have that if it wasn't for me sewing my fingers off. (She slams the loaf of bread on the table with a bang.)

The bread's stale. I hope you'll like it. You don't deserve any better, but I don't see why I should suffer.

(Going over to the stove) The coffee'll be ready in a minute, and you needn't expect me to wait for you.

(Suddenly with great anger) What on earth are you doing all this time? (She goes over to the door and looks in) Well, You're almost dressed at any rate. I expected to find you back in bed. That'd be just like you. How awful you look this morning! For heaven's sake, shave! You're disgusting! You look like a tramp. No wonder no one will give you a job. I don't blame them-when you don't even look half-way decent. (She goes to the stove) There's plenty of hot water right here. You've got no excuse. (Gets a bowl and pours some of the water from the coffee pot into it) Here.

(He reaches his hand into the room for it. It is a sensitive hand with slender fingers. It trembles and some of the water spills on the floor.)

(Tauntinglh) Look at your hand tremble. You'd better give up drinking. You can't stand it. It's just your kind that get the D.T.'s. That would be the last straw! (Looking down at the floor) Look at the mess you've made of this floor-cigarette 
butts and ashes all over the place. Why can't you put them on a plate? No, you wouldn't be considerate enough to do that. You never think of me. You don't have to sweep the room and that's all you care about.

(Takes the broom and commences to sweep viciously, raising a cloud of dust. From the inner room comes the sound of a razor being stropped.)

(Sweeping) Hurry up! It must be nearly time for me to go. If I'm late I'm liable to lose my position, and then I couldn't support you any longer. (As an afterthought she adds sarcastically) And then you'd have to go to work or something dreadful like that. (Sweeping under the table) What I want to know is whether you're going to look for a job today or not. You know your family won't help us any more. They've had enough of you, too. (After a moment's silent sweeping) I'm about sick of all this life. I've a good notion to go home, if I wasn't too proud to let them know what a failure you've been-you, the millionaire Rowland's only son, the Harvard graduate, the poet, the catch of the town-Huh! (With bitterness) There wouldn't be many of them now envy my catch if they knew the truth. What has our marriage been, I'd like to know? Even before your millionaire father died owing everyone in the world money, you certainly never wasted any of your time on your wife. I suppose you thought I'd ought to be glad you werehonorable enough to marry after getting me into trouble. You were ashamed of me with your fine friends because my father's only a grocer, that's what you were. At least he's honest, which is more than anyone could say about yours. (She is sweeping steadily toward the door. Leans on her broom for a moment.)

You hoped everyone'd think you'd been forced to marry me, and pity you, didn't you? You didn't hesitate much about telling me you loved me, and making me believe your lies, before it happened, did you? You made me think you didn't want your father to buy me off as he tried to do. I know better now. I haven't lived with you all this time for nothing. (Somberly) It's lucky the poor thing was born dead, after all. What a father you'd have been!

(Is silent, brooding moodily for a moment_then she continues with a sort of savage joy.)

But I'm not the only one who's got you to thank for being unhappy. There's one other, at least, and she can't hope to marry you now. (She puts her head into the next room) How about Helen? (She starts back from the doorway, half frightened.)

Don't look at me that way! Yes, I read her letter. What about it? I got a right to. I'm your wife. And I know all there is to know, so don't lie. You needn't stare at me so. You can't bully me with your superior airs any longer. Only for me von'd he maingr writhout breakfast this very morning. (She sets the broom back in the corner — whiningly) You never did have any gratitude for what I've done. (She comes 
to the stove and puts the coffee into the pot) The coffee's ready. I'm not going to wait for you. (She sits down in her chair again.)

(After a pause - puts her hand to her head - fretfully) My head aches so this morning. It's a shame I've got to go to work in a stuffy room all day in my condition. And I wouldn't if you were half a man. By rights I ought to be lying on my back instead of you. You know how sick I've been this last year, and yet you object when I take a little something to keep up my spirits. You even didn't want me to take that tonic I got at the drug store. (With a hard laugh) I know you'd be glad to have me dead and out of your way; then you'd be free to run after all these silly girls that think you're such a wonderful, misunderstood person-this Helen and the others. (There is a sharp exclamation of pain from the next room.)

(With satisfaction) There! I knew you'd cut yourself. It'll be a lesson to you. You know you oughtn't to be running around nights drinking with your nerves in such an awful shape. (She goes to the door and looks in.)

What makes you so pale? What are you staring at yourself in the mirror that way for? For goodness sake, wipe that blood off your face! (With a shudder) It's horrible. (In relieved tones) There, that's better. I never could stand the sight of blood. (She shrinks back from the door a little) You better give up trying and go to a barber shop. Your hand shakes dreadfully. Why do you stare at me like that? (She turns away from the door) Are you still mad at me about that letter? (Defiantly) Well, I had a right to read it. I'm your wife. (She comes to the chair and sits down again. After a pause.)

I knew all the time you were running around with someone. Your lame excuses about spending the time at the library didn't fool me. Who is this Helen, anyway? One of those artists? Or does she write poetry, too? Her letter sounds that way. I'll bet she told you your things were the best ever, and you believed her, like a fool. Is she young and pretty? I was young and pretty, too, when you fooled me with your fine, poetic talk; but life with you would soon wear anyone down. What I've been through!

(Goes over and takes the coffee off the stove) Breakfast is ready. (With a contemptuous glance) Breakfast! (Pours out a cup of coffee for herself and puts the pot on the table.) Your coffee'll be cold. What are you doing — still shaving, for heaven's sake? You'd better give it up. One of these mornings you'll give yourself a serious cut. (She cuts off bread and butters it. During the following speeches she eats and sips her coffee.)

I'll have to run as soon as I've finished eating. One of us has got to work. (Angrily) Are you going to look for a job today or aren't you? I should think some of your fine friends would help you, if they really think you're so much. But I guess they just like to hear you talk. (Sits in silence for a moment.) 
I'm sorry for this Helen, whoever she is. Haven't you got any feelings for other people? What will her family say? I see she mentions them in her letter. What is she going to do-have the child—or go to one of those doctors? That's a nice thing, I must say. Where can she get the money? Is she rich? (She waits for some answer to this volley of questions.)

Hmm! You won't tell me anything about her, will you? Much I care. Come to think of it, I'm not so sorry for her after all. She knew what she was doing. She isn't any schoolgirl, like I was, from the looks of her letter. Does she know you're married? Of course, she must. All your friends know about your unhappy marriage. I know they pity you, but they don't know my side of it. They'd talk different if they did.

(Too busy eating to go on for a second or so.)

This Helen must be a fine one, if she knew you were married. What does she expect, then? That I'll divorce you and let her marry you? Does she think I'm crazy enough for that - after all you've made me go through? I guess not! And you can't get a divorce from me and you know it. No one can say I've ever done anything wrong. (Drinks the last of her cup of coffee.)

She deserves to suffer, that's all I can say. I'll tell you what I think; I think your Helen is no better than a common streetwalker, that's what I think. (There is a stifled groan of pain from the next room.)

Did you cut yourself again? Serves you right. (Gets up and takes off her apron) Well, I've got to run along. (Peevishly) This is a fine life for me to be leading! I won't stand for your loafing any longer. (Something catches her ear and she pauses and listens intently) There! You've overturned the water all over everything. Don't say you haven't. I can hear it dripping on the floor. (A vague expression of fear comes over her face) Alfred! Why don't you answer me?

(She moves slowly toward the room. There is the noise of a chair being overturned and something crashes heavily to the floor. She stands, trembling with fright.)

Alfred! Alfred! Answer me! What is it you knocked over? Are you still drunk? (Unable to stand the tension a second longer she rushes to the door of the bedroom.)

Alfred!

(She stands in the doorway looking down at the floor of the inner room, transfixed with horror. Then she shrieks wildly and runs to the other door, unlocks it and frenziedly pulls it open, and runs shrieking madly into the outer hallway.)

(The Curtain Falls) 


\title{
Antes do Café da Manhã
}

\author{
Personagem: Sra. Rowland
}

Cena: Um cômodo pequeno que serve tanto de cozinha como sala de jantar em um apartamento na Christopher Street, Nova York. No fundo, à direita, uma porta que dá para o corredor externo. À esquerda da porta, um tanque, e um fogão a gás de duas bocas. Sobre o fogão, estendendo-se até a parede esquerda, um armário de madeira para pratos, etc. À esquerda, duas janelas que dão de frente para uma saída de incêndio onde diversas plantas em vasos estão morrendo por negligência. Diante das janelas, uma mesa coberta com uma toalha de oleado. Duas cadeiras com assento de palha estão junto à mesa. Há outra de costas para a parede à direita da porta do fundo. Na parede da direita, no fundo, uma porta que dá para um quarto. Mais à frente, diversas peças de roupa de homem e de mulher estão dependuradas em cabides. Um varal estende-se do canto esquerdo, no fundo, até a parede da direita, na frente.

São aproximadamente oito e meia de um belo dia de sol no começo do outono.

A sra. Rowland vem do quarto, bocejando, com as mãos ainda ocupadas dando os toques finais em um desleixado traje, colocando grampos em seu cabelo que está preso em um coque castanho claro no alto de sua cabeça redonda. Ela é de estatura mediana e inclina-se a uma corpulência sem forma, acentuada por seu vestido azul barato, surrado e puido. Seu rosto é inexpressivo, com traços pequenos e regulares e olhos de um azul indefinido. Há uma expressão tensa em seus olhos e nariz. sua boca sem graça e rancorosa. Ela tem vinte e poucos anos mas aparenta muito mais.

Ela vem para o meio do quarto e boceja, esticando seus braços ao máximo. Seu olhar de sono passeia pelo quarto com a irritada expressão de alguém para quem uma longa noite de sono não foi um longo descanso. Ela vai cansada até as roupas que estão dependuradas e pega um avental de um gancho. Ela o amarra na cintura, dando vazão a um exasperado "inferno" quando o nó falha em obedecer aos seus trêmulos dedos. Afinal consegue amarrá-lo e vai vagarosamente até o fogão a gás e acende uma boca. Ela enche o bule na pia e coloca-o sobre a chama. Então se joga em uma cadeira que está junto à mesa e coloca uma mão na testa como se estivesse com dor de cabeç. De repente seu rosto se ilumina como se tivesse se lembrado de algo e lança um rápido olhar para o armário de pratos. Então olha fixamente para o quarto e ouve atentamente por um instante.

Sra. Rowland: (Com voz baixa) Alfred! Alfred! (Não há resposta do quarto e ela continua suspeitosamente, agora mais alto) Não precisa fingir que tá dormindo. (Não há resposta do quarto e, tranquilizada, ela levanta da cadeira e vai, cuidadosamente, na ponta dos pés, até o armário. Ela abre uma porta devagar, tomando bastante cuidado para não fazer barulho, e arrasta, de seu esconderijo de trás dos pratos, uma garrafa de gim Gordon e um copo. 
Ao farê-lo, desloca o prato de cima, que faz um barulho. Com esse ruido ela se sobressalta e olha para a porta do quarto ao lado com uma expressão de culpa e de provocação mal humorada).

(Com a voz trêmula) Alfred!

(Depois de uma pausa, durante a qual ela presta atenção se há qualquer som, ela pega um copo e serve uma grande dose e toma-a de uma só vez; então retorna rapidamente a garrafa e o copo para o seu esconderijo. Ela fecha a porta do armário com o mesmo cuidado com que o abrira, e, com um profundo suspiro de alivio, senta-se de novo na cadeira. A grande dose de álcool que tomou tem efeito quase imediato. As feições de seu rosto tornam-se mais animadas, ela parece ganhar energia e olh a para a porta do quarto com um sorriso duro e vingativo em seus lábios. Seus olhos passeiam rapidamente pelo quarto e fixam-se em um casaco e um colete de homem que estão dependurados à direita. Ela se move furtivamente até a porta do quarto, que está entreaberta e lá fica, de maneira que não possa ser vista por ninguém lá dentro, tentando ouvir qualquer movimento.)

(Meio que sussurrando) Alfred!

(De novo, não há resposta. Com um movimento sutil, ela tira um casaco e o colete do cabide e volta para a cadeira. Ela se senta e tira diversos objetos de cada bolso, mas rapidamente os coloca de volta. Afinal, no bolso de dentro do casaco, ela encontra uma carta.)

(Olhando para a letra - devagar, para si mesma) Hum, eu sabia.

(Ela abre a carta e a lê. A princípio, sua expressão é de raiva e ódio, mas enquanto segue lendo, muda para uma expressão de triunfante maldade. Fica pensando seriamente por alguns instantes, olhando para a frente, com a carta nas mãos e um sorriso cruel nos lábios. Então coloca a carta de volta no bolso, e ainda cuidadosamente, para não acordar Alfred, coloca as roupas de volta no mesmo cabide, vai até a porta do quarto e olha para dentro.)

(Com voz alta e estridente) Alfred! (Mais alto ainda) Alfred! (Ouve-se um gemido bocejante abafado vindo do quarto) Você não acha que já tá na hora de se levantar? Você vai ficar na cama o dia inteiro? (Virando-se e retornando para a cadeira) Não que eu duvide que você é vagabundo o bastante pra ficar na cama pra sempre. (Ela se senta e olha pela janela, irritada) Sabe-se lá que horas são. A gente não tem nem como saber as horas já que você, feito um idiota, empenhou o relógio. A última coisa de valor que a gente tinha, e você sabia. Você só empenha, empenha, empenha, tudo pra não ter que pegar um emprego, qualquer coisa que impeça você de ir trabalhar feito um homem. (Ela bate o pé no chão nervosamente, mordendo os lábios)

(Depois de uma breve pausa) Alfred! Levanta, você tá me ouvindo? Eu quero fazer essa cama antes de sair. Eu tô de saco cheio dessa bagunça constante que você faz neste lugar. Não que a gente vá ficar muito tempo aqui, a não ser que você consiga algum dinheiro em algum lugar. Deus sabe que eu faço a minha 
parte - e mais - saindo pra costurar todos os dias enquanto você banca o cavalheiro e fica vagabundeando em bares com esse bando de artistas imprestáveis da Square.

(Uma pequena pausa durante a qual ela brinca nervosamente com uma xicara e um pires na mesa.)

E onde você vai conseguir o dinheiro, eu queria saber? Tem que pagar o aluguel esta semana e você sabe como que o proprietário é. Ele não vai nos deixar ficar um minuto a mais. Você diz que não 'consegue' trabalho. É mentira e você sabe disso. Você nunca nem procura trabalho. Você só fica viajando o dia inteiro: escrevendo poesia idiota e histórias que ninguém vai comprar - e não admira que não comprem. Eu sei que eu sempre consigo algum emprego, como agora; e é só por isso que nós não morremos de fome.

(Levanta-se e vai até o fogão - olha no bule para ver se a água está fervendo; depois volta e senta-se.)

Você vai ter que dar um jeito de arrumar dinheiro hoje. Eu não posso fazer tudo, e eu não vou fazer tudo. Você tem que cair na real. Você tem que mendigar, pedir emprestado ou roubar em algum lugar. (Com uma risada de desdém) Mas onde, eu queria saber? Você é orgulhoso demais pra mendigar. E você já pediu emprestado tudo o que podia, e você não tem coragem de roubar.

(Depois de uma pausa, levantando-se brava) Você ainda não se levantou, pelo amor de Deus? Por acaso você vai dormir de novo, ou vai fingir que tá dormindo? (Ela vai até a porta do quarto e olha para dentro) Ah, você se levantou. Bom, tava na hora. Não precisa me olhar desse jeito. Essa sua cara não me engana mais nem um pouquinho. Eu te conheço bem demais, melhor do que você imagina, você e as suas artimanhas. (Virando-se e afastando-se da porta, decididamente) Eu sei um monte de coisa, meu querido. Não importa o que eu sei, agora. Eu te conto antes de ir, não se preocupe. (Ela vem para o meio da sala e fica lá, de pé, franzindo o cenho.)

(Irritada) Hum. Acho que dá para eu preparar o café da manhã - não que tenha muita coisa pra preparar. (Indagando) A não ser que você tenha algum dinheiro? (Ela para esperando uma resposta da porta ao lado que não vem) Pergunta burra! (Ela dá uma risada rápida e ríspida) Eu já devia te conhecer melhor que isso a esta altura. Quando você saiu daqui ontem naquela fúria, eu sabia o que ia acontecer. Não dá pra confiar em você um segundo. Em que belo estado você chegou em casa. A briga que nós tivemos só serviu pra você virar uma fera. Pra que penhorar o relógio se você só queria o dinheiro pra comprar bebida?

(Vai até o armário de louça e pega pratos, xícaras, etc, enquanto fala.) 
Anda rápido. Não demora muito pra preparar o café da manhã hoje em dia, graças a você.

Hoje só tem pão, manteiga e café; e você não ia comer nem isso se eu não quase perdesse os dedos de tanto costurar. (Ela bate o pão com força na mesa, fažendo barulho.)

O pão tá velho. Espero que você goste. Você não merece mais que isso, mas eu não acho que eu deveria passar por isso.

(Indo até o fogão) O café vai ficar pronto rapidinho, e não fica achando que eu vou te esperar.

(De repente, com muita raiva) Que porra que você tá fazendo esse tempo todo? (Ela vai até a porta e olha para dentro) Bom, pelo menos você tá quase pronto. Eu achava que ia te encontrar na cama de novo. Ia ser a tua cara. Você tá horroroso hoje, hein?! Vai fazer a barba, pelo amor de Deus! Você tá um nojo. Parece um mendigo. Não admira que ninguém te dê trabalho. Eu não culpo eles : você com essa aparência... (Ela vai até o fogão) Tem um monte de água quente aqui. Você não tem desculpa. (Pega uma bacia e despeja um pouco da água do café) Aqui.

(Ele estica a mão para pegá-la. É uma mão frágil com dedos finos. Ela treme e cai um pouco de água no chão.)

(Zombando) Olha como você treme. É melhor você parar de beber. Você não aguenta. Você é bem o tipo que tem delirium tremens. Ia ser a gota d'água. (Olhando para o chão) Olha a porcaria que você fez no chão: pontas de cigarro e cinza por toda a parte. Por que você não coloca elas num prato? Mas não, você não tem a mínima consideração. Você nunca pensa em mim. Você não tem que varrer a sala, então você não dá bola.

(Pega a vassoura e começa a varrer freneticamente, levantando uma nuvem de poeira. Do quarto vem o som de uma navalha sendo afiada)

(Varrendo) Anda logo! Já deve tá quase na hora de eu ir. Se me atrasar, eu posso perder o emprego, e aí eu não vou poder te sustentar mais. (Como um pensamento tardio acrescenta, sarcasticamente) E aí você ia ter que ir trabalhar ou alguma coisa horrorosa desse tipo. (Varrendo embaixo da mesa) O que eu quero saber é se você vai procurar um trabalho hoje ou não!? Você sabe que a sua família não nos ajuda mais. Eles encheram o saco de você também. (Depois de varrer um pouco em silêncio) Eu tô cansada demais dessa vida. Tô pensando muito seriamente em ir pra casa, se eu não fosse orgulhosa demais pra deixar eles saberem o fracasso que você foi todo esse tempo. Você, o único filho do milionário Rowland, formado em Harvard, o poeta, o grande partido da cidade. Ahhh! (Com amargor) Quase 
ninguém ia me invejar agora se eles soubessem a verdade. O quê que foi o nosso casamento, afinal, eu queria saber? Mesmo antes do seu milionário pai morrer, devendo dinheiro pra todo mundo, você com certeza nunca perdeu nenhum tempo com a sua esposa. Acho que você pensou que eu ia ficar satisfeita por você ter sido honrado o bastante pra casar comigo depois de ter me engravidado. Você tinha vergonha de mim com seus amigos chiques porque o meu pai era um comerciante pequeno, você tinha era vergonha. Pelo menos ele é honesto, o que ninguém poderia dizer de você. (Ela está varrendo o quarto na direção da porta. Apoia-se na vassoura por um momento)

Você achou que todo mundo fosse pensar que você foi obrigado a se casar comigo, e ficar com pena de você, não é? Você não hesitou em dizer que me amava, e me fazer acreditar nas suas mentiras, antes de acontecer, não foi? Você me fez achar que você não queria que o seu pai me pagasse pra sumir, como ele tentou fazer. Eu já tô mais escolada agora. Eu não vivi esse tempo todo com você pra nada. (Sombria) Foi sorte o pobrezinho ter nascido morto, no final. Que pai você teria sido!

(Ela fica em silêncio, com ar de preocupação - então continua com certa alegria selvagem.)

Mas eu não sou a única que tem que agradecer a você por ser infeliz. Tem uma outra, pelo menos, e ela que não ache que vai casar com você agora. (Ela estica a cabeça para dentro do quarto) E essa Helen? (Ela se afasta da porta, meio que com medo)

Não me olhe desse jeito! É, eu li a carta. E daí? Eu tinha o direito de ler. Eu sou sua mulher. E eu tô sabendo de tudo, então não mente. Não adianta me olhar desse jeito. Você não me intimida mais com esse seu ar de superioridade. Se não fosse por mim, você não tinha nada pro café hoje. (Coloca a vassoura de volta no canto - gemendo) Você nunca sentiu a menor gratidão pelo que eu fiz. (Vem até o fogão e coloca café na chaleira) O café tá pronto. Eu não vou te esperar. (Senta novamente na cadeira)

(Depois de uma pausa, coloca a mão na cabeça, irritada) A minha cabeça tá doendo demais hoje. É uma vergonha eu ter que ir trabalhar naquela sala abafada nesse estado. E eu não ia precisar se você fosse mais homem. Eu é que devia não tá fazendo nada, e não você. Você sabe como eu andei doente este ano e mesmo assim você reclama quando eu tomo alguma coisinha pra me acalmar os nervos. Você não queria nem que eu tomasse aquele tônico que eu comprei na farmácia. (Com uma risada dura) Eu sei que você ia ficar contente se eu morresse e ficasse fora do seu caminho; aí você ia poder correr atrás dessas garotas bobas que acham que você é uma pessoa tão maravilhosa e incompreendida - essa Helen e as outras. (Ouve-se um grito forte de dor vindo do banheiro) 
(Contente) Aí! Eu sabia que você ia se cortar. É uma lição pra você. Você sabe que não devia andar bebendo a noite toda com os seus nervos nesse estado horroroso. (Ela vai até a porta e olha para dentro.)

Por quê que você tá tão pálido? Pra quê que você tá se olhando desse jeito no espelho? Pelo amor de Deus, limpa esse sangue do seu rosto! (Num sobressalto) Tá horrível. (Num tom mais calmo) Isso, assim tá melhor. Eu nunca aguentei ver sangue. (Ela se afasta um pouco da porta) É melhor você desistir e ir a um barbeiro. A sua mão tá tremendo tanto que dá medo. Por que você fica me olhando desse jeito? (Ela sai da porta) Você ainda tá brabo comigo por causa da carta? (Em tom de desafio) Bom, eu tinha o direito de ler a carta. Eu sou sua mulher. (Ela vai até a cadeira e senta-se de novo. Depois de uma pausa.)

Eu sabia o tempo todo que você tava andando com alguém. As suas desculpas esfarrapadas de que você passa o dia na biblioteca nunca me enganaram. Quem que é essa Helen, afinal? Uma daqueles artistas? Ou ela escreve poesia também? A letra dela parece do tipo. Eu aposto que ela disse pra você que a sua poesia é ótima, e você acreditou, feito um idiota. Ela é novinha e bonita? Eu era nova e bonita quando você me enganou com a sua conversa poética. Mas a vida com você acaba com qualquer uma. Tudo que eu passei!

(Vai até o fogão e pega o café) O café tá pronto. (Com um olhar de desdém) Café da manhã. (Serve uma xicara de café para ela e coloca a chaleira em cima da mesa) O seu café vai esfriar. O quê que você tá fazendo - se barbeando ainda, pelo amor de Deus? É melhor você desistir. Um dia desses você vai acabar se cortando feio. (Ela corta o pão e passa manteiga. Durante a próxima fala, ela come e toma café)

Eu vou ter que sair correndo assim que terminar o café. Um de nós dois tem que trabalhar. (Brava) Você vai procurar trabalho hoje ou não vai? Eu acho que algum dos seus amigos devia te ajudar, se eles acham mesmo que você é tão bom. Mas eu acho que eles só gostam de te ouvir falar. (Fica sentada em silêncio por um momento)

Eu tenho pena dessa Helen, seja lá quem ela for. Você não tem nenhum sentimento pelas outras pessoas? O quê que a família dela vai dizer? Eu vi que ela fala neles na carta. O quê que ela vai fazer - ter a criança - ou vai a um desses médicos? (Irônica) Eu acho muito bacana, eu tenho que admitir. Onde que ela pode conseguir o dinheiro? Ela é rica? (Ela espera alguma resposta para a sua saraivada de perguntas)

Hum! Você não vai me dizer nada sobre ela, vai? Eu não me importo. Pensando melhor, eu não tenho tanta pena dela assim, afinal. Ela sabia o que tava fazendo. Ela não é nenhuma garotinha de escola, como eu era, pela letra dela. Ela 
sabe que você é casado? É claro que deve saber. Os seus amigos todos sabem do seu casamento infeliz. Eu sei que eles têm pena de você, mas eles não sabem o meu lado da história. Eles iam dizer outra coisa se soubessem.

(Por um ou dois segundos, fica ocupada demais comendo para seguir falando)

Essa Helen deve ser uma boa bisca, se ela sabia que você é casado. O quê que ela tá esperando, então? Que eu me divorcie de você e deixe vocês casarem? Ela acha que eu sou louca o bastante pra fazer isso, depois de tudo o que você me fez passar? Eu acho que não! E você não vai conseguir o divórcio de mim e você sabe disso. Ninguém pode dizer que eu fiz 'qualquer' coisa errada, não mesmo. (Bebe o resto de sua xicara de café)

Ela merece sofrer, é o que eu posso dizer. Eu vou te dizer o quê que eu acho: eu acho que essa sua Helen não vale mais que uma puta de rua, é isso que eu acho. (Owve-se um gemido contido de dor do quarto ao lado)

Você se cortou de novo. Bem feito. (Levanta-se e tira o avental) Bom, eu tenho que sair correndo. (Desafiadora) É uma bela vida essa que eu tô levando! Eu não vou aguentar mais a sua vagabundagem. (Ela ouve algo e para e ouve atentamente) Isso. Você derrubou a água por cima de tudo. Não diz que não derrubou. Eu tô ouvindo pingar no chão. (Uma vaga expressão de medo vem ao rosto dela) Alfred! Por quê que você não tá respondendo?

(Ela vai lentamente na direção do quarto. Ouve-se o barulho de uma cadeira sendo derrubada e algo caindo no chão. Ela fica de pé, tremendo de medo)

Alfred! Alfred! Responde. O que foi que você derrubou? Você ainda tá bêbado? (Sem conseguir suportar a tensão nem mais um segundo, ela corre até a porta do quarto)

Alfred!

(Ela fica na porta olhando para o chão do quarto, transfigurada de horror. Então dá um grito estridente e corre para a outra porta, destranca-a e desesperadamente abre-a e sai para o corredor gritando loucamente)

Cai a cortina. 